\title{
20. The Role of the Commonwealth Environmental Water Holder
}

\author{
Daniel Connell
}

\section{Introduction}

The new governance framework for the Murray-Darling Basin (MDB) created by the Commonwealth Water Act 2007 is the first attempt to take a comprehensive approach to water management in the region. Previous arrangements applied only to a limited range of issues selected through a decision-making process requiring unanimous agreement by all governments. Realisation that many of the concerns excluded - such as the impacts of climate change-were a serious threat to future water security motivated the recent reforms. The requirement to produce a Basin Plan to be implemented through sub-plans developed by each of the States is the best-known part of the Water Act. Since the release of the Guide to the proposed Basin Plan in October 2010, it has been a major source of controversy. This chapter argues, however, that another set of provisions in the Water Act - those applying to the Commonwealth Environmental Water Holder $(\mathrm{CEWH})$ - will be even more significant in the long term.

As a result of the need to placate the States, the arrangements for the Basin Plan are complex, rigid and subject to many restraints to protect State government priorities. That makes adaptive management in response to new issues difficult and provides many opportunities for opponents to delay and frustrate its implementation. In contrast, the arrangements applying to the CEWH give the Commonwealth autonomous power to shape future water management in the MDB for the first time, particularly in relation to environmental conditions, and are a major break with the past.

The Water Act 2007 is the eighth major attempt since the 1980s to significantly shift the division of water in the MDB between production and the environment. The seven previous attempts were the Salinity and Drainage Strategy of 1989, the Natural Resources Management Strategy of 1990, the Cap mechanism of the mid 1990s, the 1994 Council of Australian Governments (COAG) rural waterreform package, the Integrated Catchment Management (ICM) Policy Statement of 2000, the Living Murray First Step project of 2003-04, and the National Water Initiative (NWI) in 2004. This chapter will highlight a number of characteristics that have been recurring themes in the history of water reform in the MDB 
by discussing four of the eight attempts to realign the balance between the environment and production: the Salinity and Drainage Strategy, the Cap, the Living Murray project and the Water Act 2007. It will argue that the Basin Plan as proposed in the Water Act-like its predecessors - is weakened by its dependence on complex and brittle intergovernmental agreements with weak or unworkable provisions for compliance.

The CEWH is different; the Commonwealth Government controls its budget and operating policies. Through the $\mathrm{CEWH}$, it will be able to achieve the environmental-flow targets of the Basin Plan even if the States do not give their support. The historical record of water reform in the MDB points to a low probability of success for arrangements that depend on close cooperation between governments. It can be argued that new arrangements need to be based on the expectation that cooperation will be variable and rarely sustained. While this might appear regrettable, it is a more realistic perspective about what is possible in a pluralist democracy such as Australia than has been the case in the past. There will always be many competing interests in the MDB. The CEWHbut not the Basin Plan - is better suited to operate in such a rough-house policy and management environment. Like its seven predecessors, the Basin Plan will probably be too delicate a flower to flourish in such conditions.

For more than 90 years - from 1915, when the River Murray Waters Agreement 1914-1915 was enacted, until the Water Act 2007-arrangements for crossjurisdictional management of the MDB depended on identical legislation enacted in parallel in the four, later six, legislatures with responsibilities in the MDB: the Commonwealth, New South Wales, Victoria, South Australia, and, more recently, Queensland and the Australian Capital Territory. The Water Act 2007 is Commonwealth legislation based on Commonwealth constitutional powers. A key provision of the earlier legislation was the requirement that all decisions be unanimous. This gave each jurisdiction the power of veto. In addition, it meant that each jurisdiction was able to demand large concessions to protect its interests in the implementation of those few policies that were approved for joint policy making. As a result, MDB policies through the 1990s and 2000s were typically low in compliance capacity and high in transaction costs resulting from provisions to protect State interests. Not surprisingly, there was frequently a very large gap between the aims expressed for a policy and the details put in place for its implementation. These characteristics shaped outcomes in the past and are a serious threat to the success of plans for the future because of their continued presence within the Water Act 2007-in particular, in the sections applying to the Basin Plan. 


\section{Salinity and Drainage Strategy, 1989}

One of the most important policies enacted in the period immediately after the reforms of the 1980s was the Salinity and Drainage (S\&D) Strategy. This strategy showed the potential that could be realised through cooperation and also the many ways in which it could be frustrated by State governments if they so wished. The Salinity and Drainage Strategy has been highly successful in containing the impact of salinity in the lower reaches of the River Murray caused by irrigation development. The wider goal of restraining other sources of degradation caused by irrigation development was, however, not achieved. Many of its original designers had thought that capping salinity impacts would also cap the volume of irrigation water that could be applied. Irrigation causes salinisation by bringing dissolved salt and by mobilising salt previously held in the soil profile. It was thought that by capping the level of acceptable salinisation, the volume of water that could be applied would also be capped.

That wider policy goal was frustrated by the way the S\&D Strategy was implemented. This involved issues that were relatively inaccessible to the wider public. One was the starting date after which remedial action would have to be undertaken to counter the salinity impacts of any irrigation development. South Australia wanted accountability for impacts under the scheme to start from a time before significant irrigation development began - early in the twentieth century. That would have made the upper States responsible for the very considerable salinity impacts of irrigation development over the previous 60 or 70 years, and substantially increased the size of their required contribution to remedial works. In response, New South Wales insisted on 1 January 1988 as the benchmark and rejected proposals to use existing levels of irrigation activity as the starting point after which all future development would be held accountable, requiring compensatory works to balance the salinity impacts. New South Wales also insisted that any future development based on the use of existing water entitlements, even though they had not yet been activated, should be excluded from the accountability process.

All three states - South Australia, New South Wales and Victoria-had some unused entitlements, but there was little awareness that in New South Wales the total was very large. (Entitlements that had been only partially activated became known as 'dozers'. Those that had not been activated at all were called 'sleepers'.) Subsequently, the Water Audit conducted in 1995 estimated that the average allocations available to diverters during the five years to 1992-93 were 16902 gigalitres, of which only 63 per cent had been activated-indicating considerable capacity to expand even without the granting of new entitlements (Murray-Darling Basin Ministerial Council 1995:8, Table 2). This additional capacity for expansion contained within the S\&D Strategy effectively destroyed 
its potential to protect the river environment from incremental erosion through increasing extraction. That early episode showed the dependence of basin-wide reform on genuine cooperation by the individual States. The great differences that exist between States makes it relatively easy for special interests to frustrate changes that might not benefit their particular region even if they are beneficial from a wider perspective.

\section{The Cap on Extractions, 1996}

Further demonstration of the capacity of the States to frustrate MDB reform by agreeing in principle but opposing in detail is provided by the history of the Cap on extractions. By the early 1990s it had become clear that the S\&D Strategy had failed to restrain the growth in extractions, and that riverine conditions in the MDB were still deteriorating. A spectacular algal bloom in the summer of 1991-92 that extended along more than $1000 \mathrm{~km}$ of the Darling River gave the issue international prominence. In June 1993, a South Australian member of the Ministerial Council, John Klunder, proposed that 'there should be no further regulation and diversions arrangements which would exacerbate deteriorating flow regimes'. He drew attention in particular to the potential for diversions to increase as a result of the utilisation of existing but previously un-activated entitlements (Klunder 1993) - the sleepers and dozers. In response, the Council commissioned an audit of water use in the MDB that was delivered in June 1995 (Murray-Darling Basin Ministerial Council 1995).

The Water Audit found that conditions were continuing to decline. In response, 'as an essential first step in establishing management systems to achieve healthy rivers and sustainable consumption uses', the Ministerial Council introduced an immediate, temporary Cap on further expansion at 1993-94 levels of development - the irrigation season upon which the Water Audit was based (Murray-Darling Basin Ministerial Council 2000:9). Introduction of the Cap in 1995 was a unanimous joint decision of the Governments of the Commonwealth, New South Wales, Victoria and South Australia (Queensland agreed in principle but never followed through in practice). The process of implementation, however, created the widespread impression that the Cap was an imposition of the Murray-Darling Basin Commission (MDBC) (in the opinion of some people that meant the Commission Office) on reluctant governments. During the 1998 federal election campaign, the Deputy Prime Minister, Tim Fischer, promised to 'zap the cap', although nothing was heard of that promise subsequently. In New South Wales in particular, the benefits of the Cap as a means to protect security of supply were poorly explained. 
When implementing its version of the Cap, New South Wales treated unactivated entitlements in the same way as it had at the time of the introduction of the S\&D Strategy in 1988. Against advice from a number of quarters, it decided once again to recognise existing entitlements that had not yet been developed. This time this approach created serious problems. In 1988, much of the political pressure that might have been created by implementation of the S\&D Strategy was avoided by allowing continued expansion of diversions by permitting activation of existing but unused entitlements. ${ }^{1}$

In 1995, however, the volume of water that New South Wales was allowed to divert as a whole under the Cap formula was fixed at the level that would have occurred under '1993/4 levels of development'. As a result, the total consumptive pool stayed about the same, but now had to be shared among a larger group of diverters, as unused entitlements were increasingly traded and activated.

Under pre-Cap arrangements, NSW Government water managers knew that a certain proportion of irrigators would not use all or any of their water, so they had customarily redistributed the surplus to established irrigators at the same low cost as was charged for the water provided as part of their entitlement. Under the new arrangements for the Cap, established irrigators now lost access to that low-cost water. To maintain their consumption at previous levels, they had to purchase what they had lost at higher prices on the water market. Not surprisingly, many of them felt that their water allocation had been cut because of the introduction of the Cap.

This created great hostility to the new system in New South Wales and generated the 'vast majority' of hostile submissions received by the five-year review of the Cap in 2000 (Murray-Darling Basin Ministerial Council 2000:27). In its final report, the review commented that some of the complainants were not receptive to advice that this was an issue that should be taken up with the relevant State government (New South Wales), not the MDB Ministerial Council or the MDB Commission. The report expressed concern about the potential created by this confusion for negative feedback and publicity that would have a detrimental impact on the Cap. This turned out to be the case and, despite repeated statements in the annual reports of the Independent Audit Group appointed to assess implementation of the Cap that much more needed to be done, there was no progress beyond the original decision to introduce the Cap at 1993-94 levels of development. As a result, the Cap was never extended to include groundwater or tightened further to achieve a more sustainable balance between irrigation and the environment, as envisaged. The approach taken to

1 No new entitlements were granted unless salinity mitigation works were undertaken to counter the salinity effects. The volume of unused existing entitlements, however, was large. During the five-year period to $1992-93$, only 63 per cent of existing entitlements were utilised. See Murray-Darling Basin Ministerial Council (1995:8, Table 2). 
implementation of the Cap is similar to that planned for the Basin Plan, which will be introduced through sub-plans to be developed by each of the States. This time there are stronger compliance provisions in place but they require extensive consultation before activation and contain great scope for disagreement about what is reasonable. As a result, the potential for the intent of the Basin Plan to be frustrated, as was the Cap, remains high.

\section{Living Murray Project, 2004}

Another major issue for the Water Act and the Basin Plan is that of transaction costs. An illustrative example of the transaction costs created by the need to respect State sensitivities is the Living Murray project, approved with funding in 2004. (The Living Murray continues as a separate project although its operation is required to be consistent with the requirements of the Water Act 2007.) It was a product of the review of the Cap conducted in 2000, which concluded that more needed to be done to arrest the continuing decline in environmental conditions and resource security. Early in the planning phase for the Living Murray, the Ministerial Council established a scientific reference panel to advise about the potential benefits of a range of rehabilitation options. Six were assessed by the panel against the probability that they would restore the River Murray to a condition that could be described as that of 'a healthy working River Murray system'. The first three-do nothing, improved operations only, and improved operations plus 340 GL for new environmental flows - were all considered to have a 'low' probability of success. Improved operations plus 750 GL was given a 'low-moderate' rating. For improved operations and $1630 \mathrm{GL}$, the probability was 'moderate'. Only 3350 GL plus improved operations was rated 'high'. Eventually, in June 2004, \$500 million was approved for use on six sites along the River Murray. At the time, it was hoped that this would result in an additional 500 GL becoming available for the environment. Subsequently, in May 2006, the Commonwealth added another $\$ 200$ million to the project plus an additional $\$ 300$ million for works that had been delayed in recent years through lack of funds.

Compared with previous efforts, the Living Murray project represented a much higher level of coordinated inter-jurisdictional activity in the MDB. It brought together a number of projects that have been under way for some time, added new ones and considerably increased the total effort invested in river rehabilitation. Existing activities included fish-ways, restoring fish habitat and a range of engineering works to make better use of environmental water. For some years, the MDBC had been installing fish-ways on its major structures so that fish would be able to move up and down the Murray over more than $2000 \mathrm{~km}$ from the Murray mouth to the foot of Hume Dam. After more than a 
century of de-snagging to improve navigation, thousands of old tree trunks are being placed back in the river to improve fish habitat. On important wetlandssuch as those in the Barmah-Millewa forests - environmental flows were being released to extend bird-breeding seasons, and engineering works and pumps were being installed so that important sites could be selectively watered. Efforts were also being made to involve Indigenous people in the planning and management of sites of particular cultural significance to them. These projects are important in themselves and also because of the opportunity they provide for water managers and policy makers to work out in practice what can be done to achieve environmental objectives on a river system subject to intense development pressure. The Living Murray was important because it brought them together as a more coherent, coordinated whole.

But the labyrinthine arrangements put in place to manage the water entitlements assigned to the Living Murray to protect State sensitivities are extraordinary. Satisfying the States' demand to maintain the maximum possible degree of autonomy appears to have taken precedence over the greater efficiency - or at least clarity - that would presumably be made possible by a single accounting system operated by a single accounting body. The structure agreed in the Intergovernmental Agreement about the MDB combined the following elements. The six signing governments agreed to commit $\$ 500$ million over five years with each jurisdiction responsible for a defined proportion. The contributions of the various States were not to be consolidated in a central fund but were to be held in the various State and Commonwealth Treasuries until needed. Working within the parameters of the Living Murray project, each government was to nominate and implement projects that met defined criteria. Jurisdictions were to have the option of investing in each other's projects up to set limits. Each would receive credit for its investment in these projects up to the value of its contribution to the $\$ 500$ million.

These financial transactions were to be recorded at both the jurisdictional level and by the MDBC - now the Murray-Darling Basin Authority (MDBA) - on behalf of the Ministerial Council, but the central registry was not to be a master registry. (This means that in the event of a dispute about a difference between records there is no final arbiter.) The intergovernmental agreement about the registers to be created to record these transactions stated that they were to be developed independently by each of the six jurisdictions subject to the general oversight of the Ministerial Council (that is, States were not required to use the same approach or criteria but merely to be 'consistent' in the opinion of the Ministerial Council - a body that was empowered only to make unanimous decisions. In other words, a State could be censored only if it agreed with the criticism of it). 
As with the plans for water recovery, the use of this saved water was also to be decentralised. Working to the Basin Environmental Watering Plan, States are to arrange for releases of the water listed on their registers at appropriate times. Subsequently, their efforts would be subject to an annual external auditing process to be conducted on behalf of the Ministerial Council. This situation was made more complicated by the fact that States and the Australian Capital Territory are entitled to trade the environmental water they have listed on their registers. As the water is moved around the Basin, it will be necessary to track where the water comes from, where it goes to and the hydrological and environmental implications of changing the point at which it is used. Detailed information about these transactions must be lodged on the registers of all the jurisdictions involved and on the central register to be run by the MDBC, now MDBA (as already noted, not a master register). Although the environmental water documented on the six registers is 'to be clearly assigned in perpetuity for the purposes of the Agreement', its component 'bits' are to be managed through the registers of the various jurisdictions that reclaimed or traded them. For all but the cognoscenti, attempting to trace these transactional trails and determine whether the environment receives the water originally assigned to it is virtually impossible. Not only will the Living Murray arrangements continue in their Byzantine glory under the new regime established by the Water Act 2007, they also provide an illuminating example of the types of accounting systems that are still being put in place across the MDB because of the pressure to protect special interests.

\section{The Water Act 2007}

The most discussed sections of the Water Act 2007 are those applying to the Basin Plan, which is to be implemented through four State plans and a plan for the Australian Capital Territory. If a State fails to develop a satisfactory plan, the Commonwealth is empowered through the Water Act 2007 to develop its own plan for that State. Before that happens a lengthy process of consultation is required. If the Commonwealth has to develop a plan, however, it would take a significant amount of additional time to complete. The Commonwealth does not possess the knowledge or capacity required and there would be considerable delay while it acquired it. In addition, there is a range of issues-involving Section 100, for example - that are likely to result in litigation. Consequently, the Basin Plan is likely to face prolonged dispute and delay before implementation.

Fortunately, however, there is a potential alternative mode of implementation contained in the Water Act - through the Commonwealth Environmental Water Holder (CEWH). Since 2007, when the Water Act was introduced, the future of water management in the Murray-Darling Basin has been transformed by 
two developments barely mentioned in the guidelines to the Basin Plan. These are the creation of the $\mathrm{CEWH}$ and the resolution of an obscure debate about whether the environment should be supplied through so-called rules-based water or through entitlements. In the coming years it is likely that the CEWH will emerge as the most important water-management institution in the MurrayDarling Basin.

The Labor Government has made a commitment that all water reclaimed through the Basin Plan will be purchased at market prices from willing sellers or come from investment in infrastructure improvements. This water will be lodged with the CEWH to be managed as entitlements for the environment. This means that the timetable for developing the State sub-plans will be almost irrelevant. In reality, the driving force behind the program will be the $\mathrm{CEWH}$-limited only by the size of its budget and any limitations that might be imposed by the Commonwealth. When the CEWH's purchasing program is complete, it will hold more than one-quarter of all water entitlements in the MDB. It will operate unfettered by constraints beyond the requirements of the Environmental Watering Plan to be developed by the MDBA - another Commonwealth agency (albeit in consultation with the States).

The long-established approach to managing rivers in the MDB has been to develop plans that allocate a proportion of the flow to entitlement-holders with the balance left in the river. Water left in the river is called rules based because it is the result of applying the management rules. But over the years it has proved difficult to protect rules-based water from encroachment by entitlementholders. The rules have always favoured entitlements when water supplies are reduced during droughts. The management rules have this bias because the original reason for building dams and regulating rivers was to supply water to agriculture and towns during the summer and in droughts when the natural flow is low. In addition, there is the burden of water theft, which the late Peter Cullen guesstimated was responsible for at least 20 per cent of all extractions. Most of that stolen water comes from the rules-based component of flow.

When they were first introduced in the early twentieth century, water allocations were very loosely defined. In recent years, they have been tightened, sharpened and designated as 'entitlements' and 'rights'. As entitlement-holders increased their certainty and the reliability of their 'rights', the risks of non-supply in overallocated systems in a highly variable climate became increasingly concentrated within the proportion of flows supposedly reserved for the environment: the rules-based component. In response, some environmental advocates argued for buying the entitlements that were previously seen as the source of the problem. That way they would have water for the environment with the same legal and security characteristics as other entitlements. But in the absence of substantial funds those scheming dreams were little more than fantasies. 
The situation was transformed by the then Prime Minister John Howard's \$10 billion water-reform package announced in January 2007, which included $\$ 3$ billion for the purchase of environmental water. Although it might have looked like a radical green gesture from some perspectives, it provided a way to reimburse irrigators for water that they were going to lose without compensation if the National Water Initiative was implemented in its original form (NWI, Paragraphs 48-9). Under the traditional approach to water management, in which the environment is supplied through rules-based water, most of the water purchased from irrigators would have been returned to the entitlement pool during times of drought because of the way the management rules work. To sceptics of the environmentally orientated campaigns to restore the MDB, this might have looked like a win-win situation. The irrigation community would get $\$ 3$ billion in compensation and then get most of the water back anyway in times of drought. The shift to supplying the environment through the use of entitlements changed that dynamic, however. Under this arrangement, that water will be permanently outside the consumptive pool. It will continue to be available to the environment even in times of severe drought (unless there is political interference with the operation of the CEWH).

\section{Bibliography}

Australian Bureau of Statistics, Australian Bureau of Agricultural and Resource Economics and Bureau of Rural Sciences 2009, Socio-economic context for the Murray-Darling Basin, Descriptive Report, MDBA Technical Report Series: Basin Plan, BP02, Murray-Darling Basin Authority, Canberra.

Australian Competition and Consumer Commission 2009, Water Trading Rules: Draft advice, Australian Competition and Consumer Commission, Canberra.

Blackmore, D. 2002, 'Protecting the future', in D. Connell (ed.), Uncharted Waters, Murray-Darling Basin Commission, Canberra.

Clark, S. D. 1971, 'The River Murray question: part II. Federation, agreement and future alternatives', Melbourne University Law Review, vol. 8, pp. 21523.

Commonwealth Parliament 1993, Murray-Darling Basin Agreement (1992), Commonwealth of Australia, Canberra.

Connell, D. 2007a, Sustainability and the National Water Initiative, Land \& Water Australia, Canberra.

Connell, D. 2007b, Water Politics in the Murray-Darling Basin, The Federation Press, Sydney. 
Council of Australian Governments (COAG) 2004, Intergovernmental Agreement on a National Water Initiative, Council of Australian Governments, Canberra, $<$ http://www.nwc.gov.au/resources/documents/IntergovernmentalAgreement-on-a-national-water-initiative.pdf $>$

Cullen, P. 2004, Interview with Peter Cullen, December, Interviewer: D. Connell, Oral History Collection, National Library of Australia, Canberra.

Davies, P., Harris J., Hillman T. and Walker K. 2008, Sustainable rivers audit: a report on the ecological health of rivers in the Murray-Darling Basin, Prepared by the Independent Sustainable Rivers Audit Group for the Murray-Darling Basin Ministerial Council, Canberra.

Department of the Attorney-General 2007, Water Act 2007, Department of the Attorney-General, Commonwealth of Australia, Canberra, <http://www.comlaw.gov.au/ComLaw/Legislation/Act1.nsf/all/search/ E511A5A262379705CA25734C001ED679>

Department of Environment, Water, Heritage and the Arts 2009, A framework for determining Commonwealth environmental water actions, Discussion Paper, Department of Environment, Water, Heritage and the Arts, Commonwealth of Australia, Canberra, <http://www.environment.gov.au/water/policyprograms/cewh/pubs/cehw-framework-discussion-paper.pdf $>$

Grafton, R. Q. and Hussey, K. 2007, 'Buying back the Living Murray: at what price?', Australasian Journal of Environmental Management, vol. 14, pp. 7481.

Grafton, R. Q. and Jiang Q. 2010, Economics of drought, water diversions, water recovery and climate change in the Murray-Darling Basin, CWEEP Research Paper 10-01, Centre for Water Economics, Environment and Policy, The Australian National University, Canberra, <http://cweep.anu.edu.au/pdf/ publications/research_papers/10-01_WaterEconomics.pdf $>$

Hamstead, M., Baldwin, C. and O'Keefe, V. 2008, Water Allocation Planning in Australia-Current practices and lessons learned, National Water Commission, Canberra.

Horridge, M., Madden, J. and Wittwer, G. 2005, 'The impact of the 2002-2003 drought on Australia', Journal of Policy Modeling, vol. 27, no. 3, pp. 285-303.

Klunder, J. 1993, The changing demands for surface water in the MurrayDarling Basin, 25 June, Submission to Murray-Darling Basin Ministerial Council Meeting No. 12, Melbourne. 
Murray-Darling Basin Authority (MDBA) 2009, Development of sustainable diversion limits for the Murray-Darling Basin, Issues Paper no. 49/09, Murray-Darling Basin Authority, Canberra, <http://www.mdba.gov.au/ files/publications/sustainable-diversion-limits-issues-paper-12-11-09.pdf $>$

Murray-Darling Basin Ministerial Council 1995, An Audit of Water Use in the Murray-Darling Basin, June, Murray-Darling Basin Ministerial Council, Canberra.

Murray-Darling Basin Ministerial Council 2000, Review of the Operation of the Cap, August, Murray-Darling Basin Ministerial Council, Canberra.

National Water Commission 2009, Australian Water Reform 2009-Second biennial assessment of progress in implementation of the National Water Initiative, September, National Water Commission, Canberra.

Senate Standing Committee on Rural and Regional Affairs and Transport 2008, Water Management in the Coorong and the Lower Lakes, Parliament of Australia, Canberra.

Tabara, D. 2005, Sustainability learning for river basin management and planning in Europe, HarmoniCOP Integration Report, HarmoniCOP Project, Work Package 6, European Commission, <http://www.harmonicop.info/_files/_ down/WP6\%20Integration \%20reportFINAL.pdf $>$

Wong, P. 2008, Rudd Government to invest \$12.9 billion in water, Media release no. PW 56/08, Parliament House, Canberra, <http://www.climatechange. gov.au/ /media/Files/minister/wong/2008/Media\%20Releases/April/ mr20080429.ashx> 